\title{
THE IMPACT OF TWO ANTICOAGULANTS ON ERYTHROCYTES MORPHOLOGY IN DIFFERENT VERTEBRATE SPECIES
}

\author{
Daniel COCAN ${ }^{1}$, Vioara MIREŞAN ${ }^{1}$, Camelia RĂDUCU ${ }^{1}$, \\ Paul UIUIU ${ }^{1}$, Alexandru GIURGIU ${ }^{1}$, Tudor PĂPUC ${ }^{1}$, \\ Radu CONSTANTINESCU ${ }^{1}$, Călin LAȚIU ${ }^{1, *}$ \\ *E-mail: calin.latiu@usamvcluj.ro
}

Received: Nov. 26, 2021. Revised: Jan. 10, 2022. Accepted: Jan. 14, 2022. Published online: Jan. 27, 2022

\begin{abstract}
In this study, we aimed to highlight the influence of anticoagulants on erythrocyte morphometry in different vertebrate species. Anticoagulants are a category of substances that inhibit blood clotting through various mechanisms. Due to this property, they are used to collect blood samples for a wide range of laboratory tests. The literature mentions that the use of anticoagulants produces morphological changes of erythrocytes, thus influencing results. Blood samples were collected from three warm-blooded vertebrate species (horse, rabbit, and chicken) and one lower vertebrate species with nucleated erythrocytes (fish) in vacutainers with Heparin and EDTA (ethylenediaminetetraacetic acid), in a normal concentration and a double concentration. At the time of harvesting, control smears were performed. In order to be able to compare the effects produced by anticoagulants on the morphology of erythrocytes, they were evaluated morphometrically at intervals of 3 , 6 , and $24 \mathrm{hrs}$. after harvest. The following features were evaluated using the Toup View software: length, width, surface and perimeter of erythrocytes for species with anucleated
\end{abstract}

erythrocytes. The same characteristics were evaluated in the nucleus for species with nucleated erythrocytes. The data obtained were processed with statistical programs to highlight changes in erythrocyte morphology produced by anticoagulants.

Keywords: blood cells; length-width ratio; cell surface; shape; vacutainer.

\section{INTRODUCTION}

Blood sampling is useful in the diagnosis of clinical diseases and also in the routine management of animal welfare (Harikrishnan et al., 2018). Research in the field of haematology and blood biochemistry in animals often involves collecting samples in anticoagulant media to maintain the liquid state of blood for a longer period (Barrelet and Ricketts, 2002). Anticoagulant use, according to some studies, frequently results in erroneous results, particularly in terms of erythrocyte indices, due to the morphological alterations that

${ }^{1}$ Faculty of Animal Science and Biotechnologies, University of Agricultural Sciences and Veterinary Medicine Cluj-Napoca, Cluj-Napoca, Romania 


\section{INFLUENCE OF ANTICOAGULANTS ON ERYTHROCYTES MORPHOLOGY IN VERTEBRATE SPECIES}

anticoagulants cause at the cellular level (Walencik and Witeska, 2007).

Usually, anticoagulants intervene and stop a certain stage of the coagulation process, but some anticoagulants stop two or more stages depending on their nature, which is why we have different types of anticoagulants depending on the investigations to be performed in hematology (Mireşan et al., 2003).

Anticoagulants are substances that inhibit the clotting process of blood or plasma, both in vivo and in vitro.

Blood samples can be drawn into tubes with a variety of preservatives, anticoagulants, and other chemicals, and then stored at room temperature, refrigerated, or frozen (World Health Organization, 2002). The goal is to keep the sample, as well as the drug or its metabolites of interest, in a stable state from the moment of collection through analysis (Kulkarni et al., 2016).

Sodium citrate, EDTA or heparin or even a gel whose density is between that of the blood cells and blood plasma are examples of additions.

Furthermore, some tubes contain additives that can maintain some blood components or chemicals, such as glucose (Kulkarni et al., 2016).

Erythrocytes are the most abundant elements in the composition of blood (Nemkov et al., 2018). Their number is expressed in units of $106 / \mathrm{mm}^{3}$ and shows variations depending on the species $\left(5 \times 106 / \mathrm{mm}^{3}\right.$ in humans, $5.5 \times 106 / \mathrm{mm}^{3}$ in cattle, $8 \times 106 / \mathrm{mm}^{3}$ in horses, $4 \times 106 / \mathrm{mm}^{3}$ in chickens, $14 \times 106 / \mathrm{mm}^{3}$ in sheep, and $7 \times 106 / \mathrm{mm}^{3}$ in pigs) (Mireşan et al., 2003). There are small variations in these values, given the age, gestational status, sex of the individual, and altitude, and may be differences between different populations of the same species. Deviations from normal values occur only in pathological cases (Mohri and Rezapoor, 2009; Ahyayauch et al., 2013). Erythrocytes transport and exchange oxygen and carbon dioxide between the respiratory system and other tissues.

Endothelial cells are activated to synthesize nitric oxide (NO).

Because the oxygenation of erythrocytes in the pulmonary capillaries favours the discharge of carbon dioxide. This induces the contraction and release of ATP and the activation of the synthesis capacity of nitric oxide by endothelial cells and its complexation with haemoglobin.

In the process of deoxygenation, the content of nitric oxide in the peripheral tissues decreases and at the same time the content of carbon dioxide increases. This causes erythrocyte swelling and vasodilation (Premont et al., 2021). The diameter of the erythrocyte is measured in $\mu \mathrm{m}$ and has the following values depending on the species: $8.3 \mu \mathrm{m}$ in humans, $7-8 \mu \mathrm{m}$ in rabbits, $3.5 \mu \mathrm{m}$ in goats, 5-6 $\mu \mathrm{m}$ in equine, and $7.5 \mu \mathrm{m}$ in chicken (Mireşan et al., 2003).

All mammals' erythrocytes are anucleated, and the majority of them are in the shape of biconcave discs termed discocytes and have a life span of approximately 120 days (Barrelet and Ricketts, 2002). Erythrocytes in fish are nucleated ellipsoidal cells with varying volumes and have a life span from 13 to 500 days. Environmental conditions and especially, water temperature and its dissolved oxygen content, seasonal changes and fish activity affect the number of erythrocytes (Witeska, 2013; Cocan et al., 2018; Uiuiu et al., 2021). 


\section{Daniel COCAN ET AL.}

Therefore, our research aimed to highlight the influence of anticoagulants on erythrocyte morphology in different vertebrate species: two species with anucleated erythrocytes (horse and rabbit) and two species with nucleated erythrocytes (chickens and fish).

\section{MATERIALS AND METHODS}

Blood samples were collected from different vertebrate species: horse (Equus caballus, Linnaeus 1758) - adult male, rabbit (Lepus europaeus, Pallas 1778) - adult male, black bullhead (Ameiurus melas, Rafinesque 1820) - adult female, and domestic chicken (Gallus gallus domesticus, Linnaeus 1758) adult female (one specimen/species). Collection methods were as follows: in horses from the jugular vein, in rabbits from the ear veins, in fish by puncturing the caudal vein, and in chickens from the ulnar veins.

After extraction, the blood samples were transferred to vacutainers where the anticoagulant is also located. For this experiment, the anticoagulants LiHep (Lithium heparin) and K3 EDTA (ethylenediaminetetraacetic acid) were used. The vacutainers were filled with blood as follows: normal anticoagulant concentration (up to the black marker found on the label of the vacutainer) and double anticoagulant concentration (up to half of the vacutainer). During blood harvesting procedures, there are situations where the operator is unable to harvest the recommended blood volume specified by the producer on the vacutainer due to age, size, and physiological status of the animal. Investigations on the effect of double anticoagulant concentration were performed to avoid situations where, at the time of blood sampling, the amount of blood indicated by the vacutainer manufacturer is not observed. The control smears were made on the spot and on a blade, a drop of blood was inserted, which was spread with the help of a blunt blade then stained with a Diakit
Panoptic quick staining kit with the three constituents: Reag-Fix Panoptic (fixator), Reag-Red Panoptic (dye with eosinophilic action), and Reag-Blue Panoptic (dye with basophilic action) to highlight the figurative elements and their fixation. From the anticoagulant vacutainers, smears were made at intervals of 3,6 , and $24 \mathrm{hrs}$. The used method was identical to that of the control samples. The effect of anticoagulants on erythrocyte morphology was evaluated at 3, 6 , and $24 \mathrm{hrs}$. after blood collection. Using the ToupView software, the following characteristics were evaluated: cell surface and length-width ratio. Cell surface and cell length-width ratio may show the deformation of the blood cells (RBC) over time under the action of different concentrations and different anticoagulants, which could result in the biased interpretation of the haematological panel.

The smears were examined with a Nikon Eclipse 50i microscope with a $60 \times$ objective. The microscope is equipped with a Nikon DS-Fil camera, and with the help of NIS-Elements Viewer 3.0, software images were taken with the following settings: fast focus $1280 \times 960$, quality capture 2560×1920, auto exposure, AECompensation $+1.0 \mathrm{EV}$, and contrast antireflex.

For each smear, 10 images were taken and 10 erythrocytes were measured from each image. A total of 15600 measurements were performed in total. The collected data were processed in Microsoft Excel and GraphPad Prism 8 software. ANOVA one-way test and Dunnett's multiple comparisons test were computed to determine the differences between the control group data and each experimental treatment.

\section{RESULTS AND DISCUSSION}

Based on the conducted experiments, it can be seen that the erythrocyte surface in horses has similar values when collected on EDTA in the 


\section{INFLUENCE OF ANTICOAGULANTS ON ERYTHROCYTES MORPHOLOGY IN VERTEBRATE SPECIES}

recommended (normal) dose and when analysed after $24 \mathrm{hrs}$. from sampling. A similar situation is encountered when analysing the surface of erythrocytes in the blood collected on a double concentration of EDTA analysed $6 \mathrm{hrs}$. after sampling. The other treatments show significant differences compared to the values of the control group (Table 1).

Heparin in double concentration, regardless of storage time $(3,6,24 \mathrm{hrs}$.), did not lead to changes in the length-width ratio of horse erythrocytes. A similar situation was obtained with the double dose of EDTA after $24 \mathrm{hrs}$. of storage.

Similar values to those of the control group of rabbit erythrocyte surface were observed for the following treatments: 3 hrs. after sample, blood obtained on EDTA in normal concentration was analysed and 6 hrs. later, blood collected on EDTA in double concentration was analysed, and blood collected on heparin in normal concentration, for both 3 and 24 hrs. after sampling (Table 2).

Table 1 - Dunnett's multiple comparisons test:

RBC surface and RBC length-width ratio in horses

\begin{tabular}{|c|c|c|c|c|c|}
\hline Control vs. & $\begin{array}{l}\text { Mean } \\
\text { Difference }\end{array}$ & $95.00 \% \mathrm{Cl}$ of diff. & Significant? & Summary & $\begin{array}{c}\text { Adjusted } \\
\text { P-value }\end{array}$ \\
\hline \multicolumn{6}{|c|}{ Horse (cell surface $-\mu m^{2}$ ) } \\
\hline EDTA-24h-Normal & -0.3988 & -0.9388 to 0.1413 & No & ns & 0.272 \\
\hline EDTA-6h-Double & 0.04657 & -0.4935 to 0.5866 & No & ns & 0.9997 \\
\hline EDTA-3h-Normal & 1.307 & 0.7673 to 1.847 & Yes & $\star \star \star * \star$ & $<0.0001$ \\
\hline EDTA-6h-Normal & 0.9765 & 0.4364 to 1.516 & Yes & $* \star * * \star$ & $<0.0001$ \\
\hline EDTA-3h-Double & 2.31 & 1.770 to 2.850 & Yes & $\star * * * *$ & $<0.0001$ \\
\hline Heparin-3h-Normal & 1.187 & 0.6466 to 1.727 & Yes & $* * * *$ & $<0.0001$ \\
\hline Heparin-6h-Normal & 2.996 & 2.456 to 3.536 & Yes & $* * * *$ & $<0.0001$ \\
\hline Heparin-24h-Normal & 1.986 & 1.446 to 2.526 & Yes & $\star * \star \star *$ & $<0.0001$ \\
\hline Heparin-24h-Double & 1.149 & 0.6087 to 1.689 & Yes & $* * * *$ & $<0.0001$ \\
\hline EDTA-24h-Double & 0.866 & 0.3260 to 1.406 & Yes & $* * *$ & 0.0001 \\
\hline Heparin-3h-Double & 0.8243 & 0.2842 to 1.364 & Yes & $* * *$ & 0.0003 \\
\hline Heparin-6h-Double & 0.6169 & 0.07685 to 1.157 & Yes & ${ }^{*}$ & 0.0155 \\
\hline \multicolumn{6}{|c|}{ Horse (cell length-width ratio) } \\
\hline EDTA-24h-Double & 0.007671 & -0.02379 to 0.03913 & No & ns & 0.9958 \\
\hline Heparin-3h-Double & -0.0157 & -0.04716 to 0.01576 & No & ns & 0.7364 \\
\hline Heparin-6h-Double & -0.01027 & -0.04173 to 0.02119 & No & ns & 0.9758 \\
\hline Heparin-24h-Double & -0.03089 & -0.06235 to 0.0005767 & No & ns & 0.0574 \\
\hline EDTA-3h-Normal & -0.2366 & -0.2680 to -0.2051 & Yes & $* * * *$ & $<0.0001$ \\
\hline EDTA-6h-Normal & -0.1431 & -0.1746 to -0.1116 & Yes & $* * * *$ & $<0.0001$ \\
\hline EDTA-24h-Normal & -0.1545 & -0.1859 to -0.1230 & Yes & $* * * *$ & $<0.0001$ \\
\hline EDTA-3h-Double & -0.09063 & -0.1221 to -0.05917 & Yes & $* * * \star$ & $<0.0001$ \\
\hline Heparin-6h-Normal & -0.06586 & -0.09733 to -0.03440 & Yes & 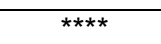 & $<0.0001$ \\
\hline Heparin-24h-Normal & -0.04309 & -0.07455 to -0.01163 & Yes & $* *$ & 0.0017 \\
\hline EDTA-6h-Double & -0.03591 & -0.06737 to -0.004449 & Yes & * & 0.0156 \\
\hline Heparin-3h-Normal & -0.03456 & -0.06602 to -0.003099 & Yes & * & 0.0226 \\
\hline
\end{tabular}

Legend: $n s$ - P-value $\geq 0.05$ (not significant); * $-\mathrm{P}$-value from 0.01 to 0.05 (significant);

${ }^{* *}$ - P-value from 0.001 to 0.01 (very significant); ${ }^{* * *}$ - P-value from 0.0001 to 0.001 (extremely significant); ${ }^{* * * *}-\mathrm{P}$-value $<0.0001$ (extremely significant) 
Regarding the length-width ratio of rabbit erythrocytes, similar values with those of the control group were observed for the treatment on EDTA in double concentration, analysed 24 hrs. after sampling. The same situation was observed in the case of heparin treatments in normal concentration after 3 and $24 \mathrm{hrs}$., and in the case of double heparin concentration in $24 \mathrm{hrs}$.

Table 2 - Dunnett's multiple comparisons test:

RBC surface and RBC length-width ratio in brown hares

\begin{tabular}{|c|c|c|c|c|c|}
\hline Control vs. & $\begin{array}{l}\text { Mean } \\
\text { Difference }\end{array}$ & $\begin{array}{l}95.00 \% \mathrm{Cl} \\
\text { of diff. }\end{array}$ & $\begin{array}{l}\text { Signi- } \\
\text { ficant? }\end{array}$ & Summary & $\begin{array}{l}\text { Adjusted } \\
\text { P-value }\end{array}$ \\
\hline \multicolumn{6}{|c|}{ Brown Hare (cell surface $-\mu m^{2}$ ) } \\
\hline EDTA-3h-Normal & 0.1671 & -0.3931 to 0.7273 & No & ns & 0.9879 \\
\hline EDTA-6h-Double & 0.03512 & -0.5251 to 0.5953 & No & ns & 0.9997 \\
\hline Heparin-3h-Normal & -0.5017 & -1.062 to 0.05851 & No & ns & 0.1057 \\
\hline Heparin-24h-Normal & -0.3999 & -0.9601 to 0.1603 & No & ns & 0.3094 \\
\hline EDTA-24h-Normal & -1.143 & -1.703 to -0.5826 & Yes & 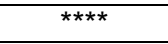 & $<0.0001$ \\
\hline EDTA-24h-Double & -1.658 & -2.219 to -1.098 & Yes & **** & $<0.0001$ \\
\hline Heparin-6h-Normal & 1.081 & 0.5208 to 1.641 & Yes & $\star \star \star * *$ & $<0.0001$ \\
\hline Heparin-3h-Double & -1.11 & -1.670 to -0.5500 & Yes & $\star \star * * *$ & $<0.0001$ \\
\hline Heparin-6h-Double & -1.166 & -1.726 to -0.6056 & Yes & $\star \star \star \star *$ & $<0.0001$ \\
\hline EDTA-3h-Double & -0.8908 & -1.451 to -0.3306 & Yes & $* * *$ & 0.0001 \\
\hline Heparin-24h-Double & -0.8978 & -1.458 to -0.3376 & Yes & $\star * \star *$ & 0.0001 \\
\hline EDTA-6h-Normal & -0.74 & -1.300 to -0.1798 & Yes & ** & 0.0028 \\
\hline \multicolumn{6}{|c|}{ Brown Hare (cell length-width ratio) } \\
\hline EDTA-24h-Double & -0.00312 & -0.03108 to 0.02483 & No & $\mathrm{ns}$ & 0.9996 \\
\hline Heparin-3h-Normal & 0.008082 & -0.01987 to 0.03603 & No & ns & 0.9896 \\
\hline Heparin-24h-Normal & -0.0175 & -0.04545 to 0.01045 & No & ns & 0.467 \\
\hline Heparin-24h-Double & -0.00782 & -0.03578 to 0.02013 & No & ns & 0.9907 \\
\hline EDTA-3h-Normal & -0.09635 & -0.1243 to -0.06840 & Yes & 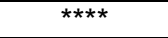 & $<0.0001$ \\
\hline EDTA-6h-Normal & -0.1529 & -0.1808 to -0.1249 & Yes & $\star \star \star \star *$ & $<0.0001$ \\
\hline EDTA-24h-Normal & -0.09613 & -0.1241 to -0.06818 & Yes & $\star \star \star * *$ & $<0.0001$ \\
\hline EDTA-3h-Double & -0.07722 & -0.1052 to -0.04926 & Yes & $* * * *$ & $<0.0001$ \\
\hline EDTA-6h-Double & -0.05241 & -0.08036 to -0.02446 & Yes & $* * * *$ & $<0.0001$ \\
\hline Heparin-3h-Double & -0.04061 & -0.06856 to -0.01265 & Yes & $* * *$ & 0.0007 \\
\hline Heparin-6h-Normal & -0.03689 & -0.06484 to -0.008935 & Yes & ** & 0.0028 \\
\hline Heparin-6h-Double & -0.03545 & -0.06340 to -0.007494 & Yes & $\star *$ & 0.0048 \\
\hline
\end{tabular}

The symbols used have the same meaning as in Table 1

As can be seen in Table 3, for chicken erythrocytes, similar cell surface values to those of the control group were observed in the following treatments: EDTA in normal concentration at 3 and 24 hrs. after sampling, EDTA in double concentration at $24 \mathrm{hrs}$. after sampling, and in the case of heparin in normal concentration, $3 \mathrm{hrs}$. after sampling. Regarding the length-width ratio, all treatments showed extremely significant differences, compared to the control group.

For black bullhead (Table 4), the erythrocyte surface had values similar to those of the control group when the blood was collected on heparin in normal concentration and analysed $6 \mathrm{hrs}$. after sampling and in double heparin concentration, analysed 3 hrs. after 


\section{INFLUENCE OF ANTICOAGULANTS ON ERYTHROCYTES MORPHOLOGY IN VERTEBRATE SPECIES}

sampling. Regarding the length-width ratio of erythrocytes in black bullhead, we obtained values similar to those of the control group in the following treatments: blood collected on EDTA in double concentration and analysed $24 \mathrm{hrs}$. after sampling, and for blood collected on heparin in double concentration and analysed 3, 6, and $24 \mathrm{hrs}$. after sampling.

Table 3 - Dunnett's multiple comparisons test:

RBC surface and RBC length-width ratio in chickens

\begin{tabular}{|c|c|c|c|c|c|}
\hline Control vs. & $\begin{array}{l}\text { Mean } \\
\text { Difference }\end{array}$ & $\begin{array}{l}95.00 \% \mathrm{Cl} \\
\text { of diff. }\end{array}$ & $\begin{array}{l}\text { Signifi- } \\
\text { cant? }\end{array}$ & Summary & $\begin{array}{l}\text { Adjusted } \\
\text { P-value }\end{array}$ \\
\hline \multicolumn{6}{|c|}{ Chicken (cell surface $-\mu m^{2}$ ) } \\
\hline EDTA-3h-Normal & 0.3882 & -0.3809 to 1.157 & No & $\mathrm{ns}$ & 0.7243 \\
\hline EDTA-24h-Normal & 0.5168 & -0.2523 to 1.286 & No & ns & 0.3799 \\
\hline EDTA-24h-Double & -0.5377 & -1.307 to 0.2314 & No & ns & 0.333 \\
\hline Heparin-3h-Normal & -0.7686 & -1.538 to 0.0004981 & No & ns & 0.0503 \\
\hline EDTA-6h-Double & 1.401 & 0.6321 to 2.170 & Yes & $* * * *$ & $<0.0001$ \\
\hline Heparin-3h-Double & -5.744 & -6.513 to -4.975 & Yes & 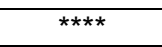 & $<0.0001$ \\
\hline Heparin-24h-Double & -1.662 & -2.431 to -0.8930 & Yes & $\star * * * *$ & $<0.0001$ \\
\hline Heparin-24h-Normal & -1.126 & -1.895 to -0.3566 & Yes & $* \star *$ & 0.0006 \\
\hline Heparin-6h-Double & -1.14 & -1.909 to -0.3712 & Yes & *** & 0.0005 \\
\hline EDTA-6h-Normal & -0.9388 & -1.708 to -0.1697 & Yes & 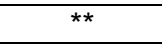 & 0.0076 \\
\hline EDTA-3h-Double & 1.05 & 0.2814 to 1.820 & Yes & ** & 0.0018 \\
\hline Heparin-6h-Normal & -0.9569 & -1.726 to -0.1878 & Yes & ** & 0.006 \\
\hline \multicolumn{6}{|c|}{ Chicken (cell length-width ratio) } \\
\hline EDTA-3h-Normal & 0.2393 & 0.1820 to 0.2965 & Yes & 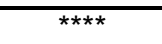 & $<0.0001$ \\
\hline EDTA-6h-Normal & 0.2627 & 0.2054 to 0.3200 & Yes & $\star \star \star \star *$ & $<0.0001$ \\
\hline EDTA-24h-Normal & 0.2812 & 0.2239 to 0.3385 & Yes & $* * * *$ & $<0.0001$ \\
\hline EDTA-3h-Double & 0.1736 & 0.1163 to 0.2308 & Yes & $* * * *$ & $<0.0001$ \\
\hline EDTA-6h-Double & 0.136 & 0.07878 to 0.1933 & Yes & $* * \star \star *$ & $<0.0001$ \\
\hline EDTA-24h-Double & 0.1963 & 0.1390 to 0.2536 & Yes & $\star \star * \star *$ & $<0.0001$ \\
\hline Heparin-3h-Normal & 0.1654 & 0.1082 to 0.2227 & Yes & 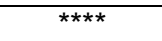 & $<0.0001$ \\
\hline Heparin-6h-Normal & 0.1947 & 0.1375 to 0.2520 & Yes & $* * * *$ & $<0.0001$ \\
\hline Heparin-24h-Normal & 0.3381 & 0.2808 to 0.3953 & Yes & $\star * * * *$ & $<0.0001$ \\
\hline Heparin-3h-Double & 0.4164 & 0.3591 to 0.4737 & Yes & 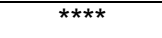 & $<0.0001$ \\
\hline Heparin-6h-Double & 0.2171 & 0.1599 to 0.2744 & Yes & 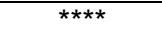 & $<0.0001$ \\
\hline Heparin-24h-Double & 0.1595 & 0.1022 to 0.2168 & Yes & $* * * \star$ & $<0.0001$ \\
\hline
\end{tabular}

The symbols used have the same meaning as in Table 1

Fig. 1 and Fig. 2 show the mean values of surfaces and the length-width ratios of erythrocytes for the analysed species (Fig. 1) vertical axis shows mean values of erytrocite surfaces and Fig. 2 shows mean values of length-width ratio of erytrocites). Changes in these parameters can be observed depending on the anticoagulant used, its concentration, and the time of blood storage in the vacutainer. Due to the gradient differences between the internal medium of erythrocytes and anticoagulants, fluctuations of the studied parameters were observed.

Other previous studies (SanchezMigallon et al., 2008) analysed the impact of different anticoagulants on haematological values. Our results come in addition to the literature with quantitative data on erythrocyte morphology. 
Table 4 - Dunnett's multiple comparisons test:

RBC surface and RBC length-width ratio in black bullheads

\begin{tabular}{|c|c|c|c|c|c|}
\hline Control vs. & $\begin{array}{l}\text { Mean } \\
\text { Difference }\end{array}$ & $\begin{array}{c}95.00 \% \mathrm{Cl} \\
\text { of diff. }\end{array}$ & $\begin{array}{l}\text { Signifi- } \\
\text { cant? }\end{array}$ & Summary & $\begin{array}{l}\text { Adjusted } \\
\text { P-value }\end{array}$ \\
\hline \multicolumn{6}{|c|}{ Black bullhead (cell surface $\left.-\mu m^{2}\right)$} \\
\hline Heparin-6h-Normal & -0.2708 & -1.362 to 0.8200 & No & ns & 0.9957 \\
\hline Heparin-3h-Double & 0.8569 & -0.2339 to 1.948 & No & ns & 0.2095 \\
\hline EDTA-3h-Normal & 5.064 & 3.974 to 6.155 & Yes & $* * * *$ & $<0.0001$ \\
\hline EDTA-6h-Normal & 5.006 & 3.915 to 6.097 & Yes & $\star \star * * *$ & $<0.0001$ \\
\hline EDTA-24h-Normal & 2.498 & 1.407 to 3.589 & Yes & 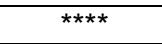 & $<0.0001$ \\
\hline EDTA-3h-Double & 5.014 & 3.923 to 6.105 & Yes & $\star \star \star \star *$ & $<0.0001$ \\
\hline EDTA-6h-Double & 4.284 & 3.193 to 5.374 & Yes & 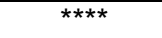 & $<0.0001$ \\
\hline EDTA-24h-Double & 5.516 & 4.426 to 6.607 & Yes & 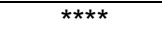 & $<0.0001$ \\
\hline Heparin-6h-Double & 3.016 & 1.925 to 4.107 & Yes & $* * * *$ & $<0.0001$ \\
\hline Heparin-24h-Double & 1.915 & 0.8241 to 3.006 & Yes & $* * * *$ & $<0.0001$ \\
\hline Heparin-3h-Normal & 1.689 & 0.5985 to 2.780 & Yes & $* * *$ & 0.0002 \\
\hline Heparin-24h-Normal & -1.725 & -2.816 to -0.6344 & Yes & $* * *$ & 0.0002 \\
\hline \multicolumn{6}{|c|}{ Black bullhead (cell length-width ratio) } \\
\hline EDTA-24h-Double & -0.03833 & -0.1172 to 0.04054 & No & $\mathrm{ns}$ & 0.7629 \\
\hline Heparin-3h-Double & -0.04164 & -0.1205 to 0.03723 & No & ns & 0.675 \\
\hline Heparin-6h-Double & -0.04954 & -0.1284 to 0.02933 & No & ns & 0.4631 \\
\hline Heparin-24h-Double & -0.06006 & -0.1389 to 0.01881 & No & ns & 0.24 \\
\hline EDTA-3h-Normal & -0.2287 & -0.3075 to -0.1498 & Yes & $* * * *$ & $<0.0001$ \\
\hline EDTA-6h-Normal & -0.2272 & -0.3061 to -0.1484 & Yes & 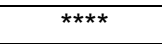 & $<0.0001$ \\
\hline EDTA-24h-Normal & -0.1757 & -0.2546 to -0.09686 & Yes & $\star * * *$ & $<0.0001$ \\
\hline Heparin-3h-Normal & -0.3179 & -0.3968 to -0.2390 & Yes & $\star \star \star \star *$ & $<0.0001$ \\
\hline Heparin-6h-Normal & -0.1875 & -0.2664 to -0.1086 & Yes & $\star \star \star \star *$ & $<0.0001$ \\
\hline Heparin-24h-Normal & 0.1046 & 0.02575 to 0.1835 & Yes & ** & 0.0026 \\
\hline EDTA-3h-Double & -0.08738 & -0.1663 to -0.008513 & Yes & * & 0.0209 \\
\hline EDTA-6h-Double & -0.08084 & -0.1597 to -0.001969 & Yes & * & 0.0412 \\
\hline
\end{tabular}

The symbols used have the same meaning as in Table 1

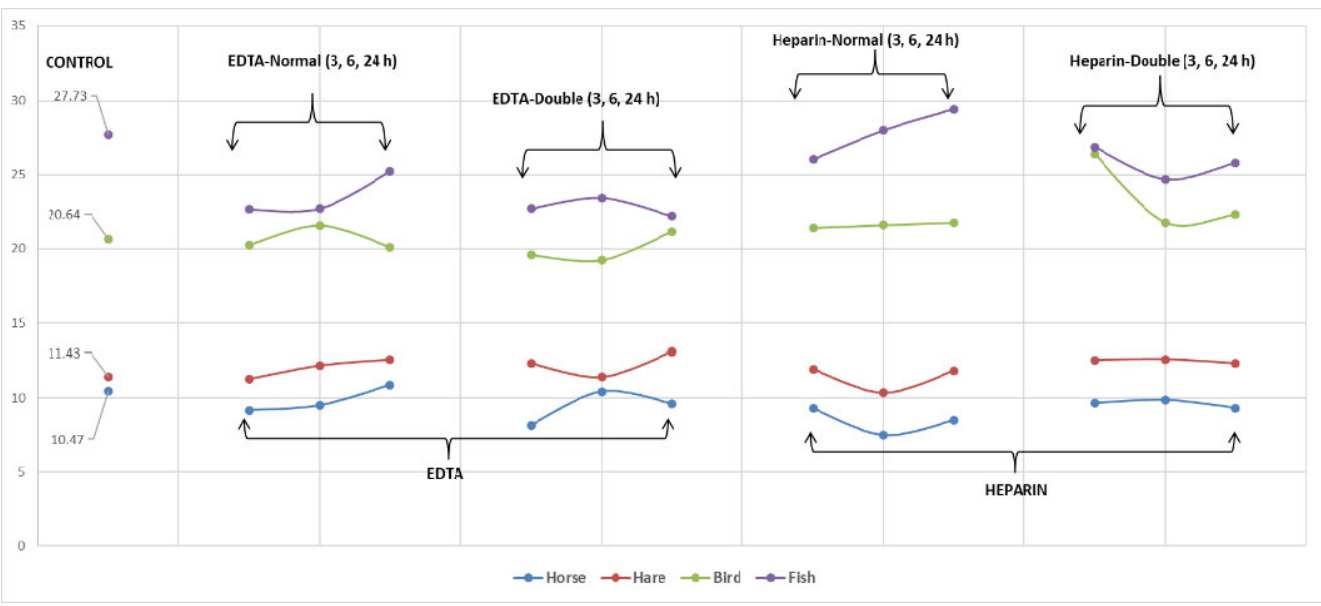

Figure 1 - Mean values distribution of red blood cells surfaces 


\section{INFLUENCE OF ANTICOAGULANTS ON ERYTHROCYTES MORPHOLOGY IN VERTEBRATE SPECIES}

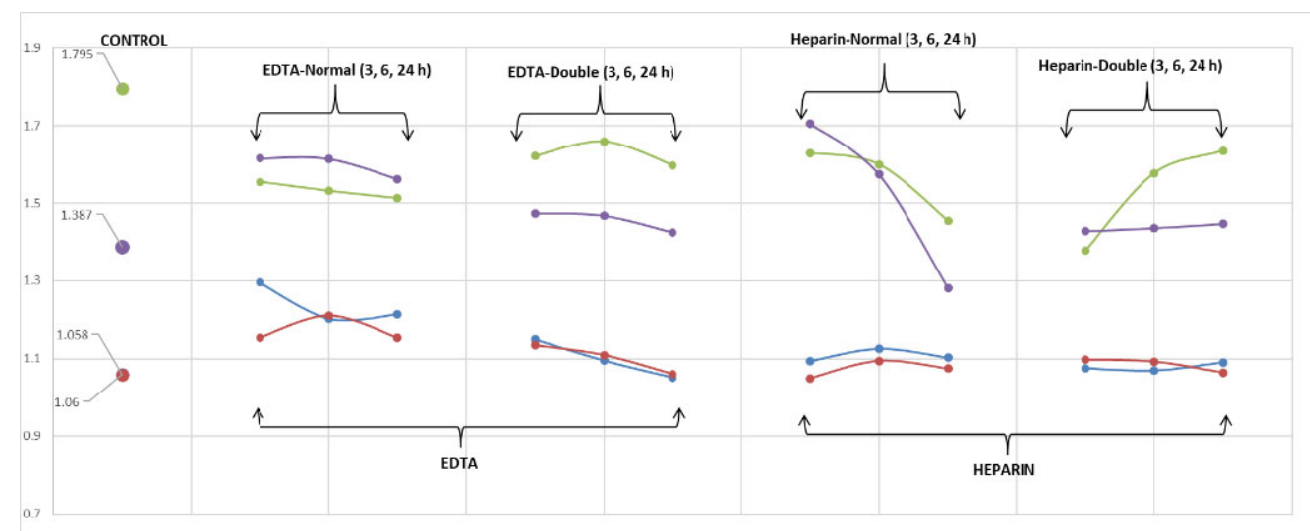

$\rightarrow$-Horse $\rightarrow$-Hare $\rightarrow$ Bird $\rightarrow$ - Fish

Figure 2 - Mean values distribution of the length-width ratio for red blood cells

\section{CONCLUSIONS}

The anticoagulant type, its concentration, and the exposure time of the blood to the anticoagulant are factors that can influence the quality and accuracy of blood analyses. In the tables and figures presented, the recommended concentrations for both types of anticoagulants and the optimal blood analysis time marks can be identified. Failure to observe the recommended concentrations for different types of anticoagulants and the time of exposure of erythrocytes to them may lead to morphological changes. These changes from the increase or decrease in volume can negatively influence certain haematological parameters, in particular haematocrit values. Anticoagulants are isotonic with the internal medium of mammals. In the case of lower vertebrates (birds, fish, reptiles, amphibians), anticoagulants may induce morphological changes in erythrocytes, as the latter have a lower concentration in the internal medium.

\section{REFERENCES}

Ahyayauch, H., Sansar, W., RendonRamirez, A., Goñi, F.M., Bennouna, M. \& Gamarani, H. (2013). Effects of chronic and acute lead treatments on the biophysical properties of erythrocyte membranes and a comparison with model membranes. FEBS Open Bio, 3: 212-217, DOI: 10.1016/j.fob.2013.04. 001.

Barrelet, A. \& Ricketts, S. (2002). Haematology and blood biochemistry in the horse: a guide to interpretation. In: Practice, 24: 318-327, DOI: 10.1136/ inpract.24.6.318.

Cocan, D., Popescu, F., Laţiu, C., Uiuiu, P., Coroian, A., Răducu, C., Coroian, C., Mireşan, V., Kokkinakis, A. \& Constantinescu, R. (2018). Effects of thermal stress on hematological and metabolic profiles in brown bullhead, Ameiurus nebulosus (Lesueur, 1819). AgroLife Sci. J., 7(1): 33-41.

Guzman, D.S., Mitchell, M.A., Gaunt, S.D., Beaufrère, H. \& Tully, T.N. (2008). Comparison of hematologic values in blood samples with lithium heparin or dipotassium ethylenediaminetetraacetic acid anticoagulants in Hispaniolan Amazon parrots (Amazona ventralis). $J$. Avian Med. Surg., 22(2): 108-113, DOI: 10.1647/2007-011.1. 
Harikrishnan, V.S., Hansen, A.K., Abelson, K.S.P. \& Sørensen, D.B. (2018). A comparison of various methods of blood sampling in mice and rats: Effects on animal welfare. Lab. Anim., 52(3): 253-264, DOI: 10.1177/0023677 217741332.

Kulkarni, P., Karanam, A., Gurjar, M., Dhoble, S., Naik, A.B., Vidhun, B.H. \& Gota, V. (2016). Effect of various anticoagulants on the bioanalysis of drugs in rat blood: implication for pharmacokinetic studies of anticancer drugs. SpringerPlus, 5(1): 2102, DOI: 10.1186/s40064-016-3770-4.

Lulijwa, R., Alfaro, A.C., Young, T., Venter, L., Decker, P., Merien, F. \& Meyer, J. (2021). Effect of anticoagulants on farmed giant kokopu, Galaxias argenteus (Gmelin, 1789) haematological parameters and erythrocyte fragility. J. Fish Biol., 99(2): 684-689, DOI: 10.1111/jfb.14746.

Mireşan, V., Eresk, A. \& Răducu, C. (2003). Physiology of domestic animals (In Romanian). Cluj-Napoca, Ed. Risoprint.

Mohri, M. \& Rezapoor, H. (2009). Effects of heparin, citrate, and EDTA on plasma biochemistry of sheep: Comparison with serum. Res. Vet. Sci., 86(1): 111114, DOI: 10.1016/j.rvsc.2008.05.010.

Nemkov, T., Reisz, J.A., Xia, Y., Zimring, J.C. \& D'Alessandro, A., (2018). Red blood cells as an organ? How deep omics characterization of the most abundant cell in the human body highlights other systemic metabolic functions beyond oxygen transport. Expert Rev. Proteomic., 15(11), 855864. DOI: $10.1080 / 14789450.2018 .153$ 1710.

Premont, R.T., Reynolds, J.D., Zhang, R. \& Stamler, J.S. (2021). Red blood cellmediated S-nitrosohemoglobindependent vasodilation: Lessons learned from a $\beta$-globin Cys93 knock-in mouse. Antioxid. Redox Signal., 34(12): 936-961, DOI: 10.1089/ars.2020.8153.

Uiuiu, P., Lațiu, C., Păpuc, T., Craioveanu, C., Ihuț, A., Sava, A., Răducu, C., Şonea, C., Constantinescu, R., Cocan, D. \& Mireșan, V. (2021). Multiapproach assessment for stress evaluation in rainbow trout females, Oncorhynchus mykiss (Walbaum, 1792) from three different farms during the summer season. Animals, 11(6): 1810, DOI: 10.3390/ani11061810.

Walencik, J. \& Witeska, M. (2007). The effects of anticoagulants on hematological indices and blood cell morphology of common carp (Cyprinus carpio L.). Comp. Biochem. Physiol. C Toxicol. Pharmacol., 146(3): 331-335, DOI: 10.1016/j.cbpc.2007.04.004.

Witeska, M. (2013). Erythrocytes in teleost fishes: a review. Zool. Ecol., 23(4): 275281, DOI: $10.1080 / 21658005.2013 .846$ 963.

World Health Organization (2002). Use of anticoagulants in diagnostic laboratory investigations. Geneva, 62 p

(C) 2021 by the authors; licensee Journal of Applied Life Sciences and Environment, Iasi, Romania. This article is an open access article distributed under the terms and conditions of the Creative Commons Attribution License (http://creativecommons.org/licenses/by/4.0/). 